\title{
Trade, Investment and Growth Nexus in Pakistan: An Application of Cointegration and Multivariate Causality Test
}

\section{Aurangzeb*}

\begin{abstract}
This paper develops a multivariate model to test the causality between exports and investment and economic growth in Pakistan. Most of the previous studies in this area have not paid any attention to stationarity and co-integration issues. The underlying series are tested and it was found that the series are non-stationary in their levels and not co-integrated. The Hsiao's version of the Granger Causality method is used, the order in which the variables are entered into the model is also considered by using (SG) criterion, which is very important in the multivariate frame work and it improves the robustness of the causality results. The results show that there exists a strong bi-directional causality between exports growth and investment growth to GDP growth. It was also found that exports growth causes imports growth, investment growth causes exports growth, and imports growth causes GDP growth and investment growth, but not the opposite. These findings support the fact that both exports and investment are considered as an engine of growth in Pakistan. The causal inferences are fairly stable over the sample period.
\end{abstract}

\section{Introduction}

In the last two decades most development economists have exhibited increasing interest in the relationship between export expansion and economic growth in the context of the suitability of the alternative development strategies. Four different views can be distinguished, not all of which are mutually exclusive. The first is the neo-classical export-led growth hypothesis. This theory suggests that the direction of causation is from export to economic growth for the following reasons: (i) export expansion will increase productivity by offering greater economies of scale (Helpman and Krugman 1985), (ii) export expansion brings about higher quality products because of the exporter's exposure to international consumption patterns

\footnotetext{
* The author is Research Officer at the Social Policy \& Development Centre, (SPDC) Karachi.
} 
(Krueger 1985), (iii) it will lead a firm to over-invest in new technology as a strategy for pre-commitment to a large scale of output increasing the rate of capital formation and technological change (Rodrik,1988), (iv) an exportoriented approach in a labour-surplus economy permits the rapid expansion of employment and real wages (Krueger, 1985) and, (v) exports contribute to a relaxation of foreign exchange constraints that normally impinge on development efforts (Voivodas,1973, Afxentiou and Serletis , 1992).Finally due to the competition in the world market, domestic firms are forced to reduce inefficiencies (Yaghamaian, 1994).

The second view is that the causality runs from economic growth to exports. This is because higher productivity leads to lower unit costs which facilitate exports (Kaldor,1967). Economic growth causes export growth if innovation and technical progress result in well-developed markets which improve export performance in the trade sector (Vernon,1966; Ghartey 1993). If domestic production is in excess of domestic demand, then producers are likely to sell the surplus goods in the foreign market (Sharma and Dhakal, 1994).

The third view is the combination of the first and second: there can be a bi-directional causal relationship between exports and economic growth (Helpman and Krugman, 1985;Kunst and Marin, 1989; Ghartey, 1993; Sharma and Dhaka1, 1994).

The fourth view is that no causal relationship exists between exports and economic growth. Exports and economic growth are both the results of the process of development and structural change (Pack, 1988,1992 and Yaghamian, 1994). The strong theoretical arguments presented for both the first and the second views ultimately support the hypothesis that there can be a causal relationship between economic growth and exports in either direction. The hypothesis of a causal relationship between exports and economic growth does not imply that exports are the only determinant of economic growth or vice-versa. Several studies contribute to explaining the relationship between export expansion and economic growth, but very few investigations have been made to test the causality between economic growth and exports plus imports (openness). Although most researchers talk about trade policy but in their discussion they focus exclusively on export policy. Does it mean that imports do not help a country?

Though it has been clearly observed that exports create domestic income and employment, imports create income and employment for foreigners. Thus, other things being equal, exports tend to increase our total national income and imports reduce it. Surely then, it is desirable to encourage exports by subsidising them and to discourage imports by taxing them. This is 
an appealing argument but it is incorrect. Exports raise national income by adding to the value of domestic output, but they do not add to the value of domestic consumption. In fact exports are goods produced at home and consumed abroad, while imports are goods produced abroad and consumed at home. If exports were really good and imports were really bad then a fully employed economy that managed to increase exports without a corresponding increase in imports ought to be better off. However it has been a fact that exports permit imports to be made. This two-way international exchange is valuable because more goods can be imported than could be obtained if the same goods were produced at home. Now the question arises, why should imports not be related to economic growth? And why the publication of high import statistics in the newspaper stirs government officials? They feel compelled to defend such high import statistics. This thinking has arisen from the macroeconomic argument that imports represent a leakage from the circular flow of income and will lead to domestic unemployment rather than economic growth. Economic literature seems to follow the same line: issues of trade are always implicitly taken to mean issues of export. However, it is now extensively argued that imports of capital goods and energy can help economic growth for LDCs. Nonetheless, imports are traditionally treated as functions of national income (Afxentiou and Serletis, 1992; Liu Song and Romilly, 1997). The way in which imports are related to growth is that it helps in removing the shortfalls of technological needs, so that an increase in the market size or in the availability of production technology affects the returns to innovation, and hence leads to higher stable growth rates. So one may say that there must be a unidirectional or bi-directional relationship between exports, imports and economic growth.

Another set of ideas link openness with growth. However there is no unique measure of openness in the literature because of the multi-faceted nature of trade policies; and indeed various different openness measures are loosely used to cover the different concepts, resulting in considerable confusion of terminology (see e.g. Krishna (1992)), and also these different measures of openness are uncorrelated with each other as shown by Pritchett (1996). The most common measure of openness is the ratio of total trade to national income or exports and imports to GNP (Jung and Marshall ,1985; Chow ,1987;Kunst and Marin ,1989; Sheehey 1990;Bahmani-Oskooee et al,1991; Bahmani-Oskooee and Alse, 1993; Dodaro, 1993; Sharma and Dhakal, 1994; Serletis, 1992; Ghartey ,1993; Gordon and Sakyi-Bekoe, 1993; Arnade and Vasavada, 1995; Khan, Malik and Hasan, 1995; Abhayaratne, 1996; Doraisami, 1996; Liu et al, 1997; Islam, 1998).

Krishna (1992) shows that such trade share measures are the indices of vulnerability to the terms of trade. One caveat of trade share measures is 
that they do not necessarily serve as an adequate measure of the strength of trade barriers; small countries tend to have larger trade shares then larger ones, ceteris paribus.

The other strand of literature uses a production-based regression model in order to link trade policy to growth (Ben-David and Loewy, 1997; Michealy 1977; Kruger 1978; Tyler 1981; Kavousi, 1984; Feder, 1982; Balassa, 1985; Mbaku, 1989; Moschos, 1989; Salvator and Hatch ,1991; Yaghmaian, 1994). These models can identify the relationship between economic growth and exports in an alternative growth equation which includes various factors of production, and in some cases the process of development and structural change (Timmer, 1988; Syrquin, 1988; Yaghmaian, 1994).

Finally, it should be noted that one set of ideas links investment and growth with exports. An increase in exports is related with growth because the higher investment demand causes a rise in exports (see Rodrik (1995)). Similarly, Young (1994) argues that in contrast to export led growth, the success of the NICs could also be explained by policies that promoted investment. According to this view investment would be related prior to GDP.

It is possible that all the discussion which has been taking place is headed in the wrong direction and that in fact, everything causes everything else! Thus one may say that it is growth that causes exports or investment rather than the other way around. An obvious way to address this issue empirically is to look for evidence of causality, but unfortunately the evidence which has been uncovered to date has been mixed. The reasons behind these mixed or contradictory causality results are that these results are affected by the problem of misspecification, such as the omission of a relevant variable (e.g. investment, imports etc.) or because of ignoring the probable presence of a stochastic trend common to all variables in the question, simply by ignoring the integration properties of the series in hand. As a result the parameter estimates are likely to be biased and inconsistent, leading to a misleading causal link. For example, if changes in government policy affect economic growth more rapidly than trade expansion, growth spuriously appears to cause trade, even though they may in fact be causally unrelated.

In most of the previous research in this area the Granger causality test is applied on annual data of exports and GDP. Unfortunately, the results of the Granger causality test are very sensitive to the selection of lag length. If the appropriate lag length is not selected the results will suffer from the specification error and the inferences which will be drawn on the basis of the Granger test will no longer be valid. In order to remove this 
deficiency, Hsiao's approach (Hsiao (1979, 1981)) is employed in this study. Thornton and Batten (1985) demonstrated that Hsiao's method is superior to both arbitrary lag length selection and several other systematic procedures for determining lag length. This FPE criterion that we use in this study is appealing, as Hsiao (1981) points out that it balances the risk of selecting a higher lag against the risk of a lower lag.

Hsiao's method works well in a bivariate framework. Whereas in a multivariate framework, it does not ensure that the results of the autoregressive (AR) equation will remain the same when the order in which regressors are introduced is changed. In order to overcome this problem, we employed Specific Gravity Criterion (SGC) as proposed by Caines, Keng and Sethi (1981), to determine the sequence in which the regressors are added at each stage ${ }^{1}$.

Thus our contribution to the literature is twofold. On the methodological side by adopting Specific Gravity Criterion we are able to attenuate the specification bias and increase the robustness of the causal inferences. On the analytical by including imports as well as investment in our analysis, we can assess whether our model is capable of predicting the turning points in growth in Pakistan. The purpose of this exercise is to solve the problem of causality between exports and growth which still remains unsolved. We use annual time-series data covering the period from 1973 to 2001. The annual series were taken from the various issues of the Economic Survey of the Ministry of Finance, Pakistan. The rest of the paper is organised as follows: In section II we discuss the methodological approach used in the paper, and in section III we present the empirical results. In these two sections the integration properties of the data are analysed and co-integration tests are carried out to determine whether an error-correction is needed. Section IV is a summary and conclusion.

\section{The Methodology}

The Granger causality test as proposed by Hsiao (1981) is applied in this study. Hsiao's test follows a two step procedure to determine the optimum lag length (using Akaike's FPE criteria (Akaike, (1969)) and at the same time the direction of causality.

The test procedure is given as follows; initially we treat the dependent variable $y_{t}$ as a one-dimensional AR process. We then compute the sum of squared errors (SSE) using the same equation with the maximum order of lags varying from $1, \ldots ., \mathrm{m}$. The corresponding FPE as defined by

\footnotetext{
${ }^{1}$ See Caines, Keng, and Sethi (1981)
} 
Akaike (1969) is calculated using the following equation. We then choose the order $\operatorname{AR}\left(\mathrm{m}^{*}\right)$ which yields the smallest FPE.

$F P E=\frac{T+m+1}{T-m-1} \frac{S S E}{T}$

Then we add one lag at a time the causal variable $x_{t}$ to the $\operatorname{AR}\left(m^{*}\right)$ model cumulatively and calculate the corresponding $\mathrm{FPE}_{\mathrm{m}, \mathrm{j} \text { 's }}$, where $j=1, \ldots \ldots, \mathrm{n}$. The smallest $\mathrm{FPE}_{\mathrm{m}, \mathrm{n}}^{* *}$ (where $\mathrm{n}^{*}$ is the lag length of $\mathrm{x}_{\mathrm{t}}$ that minimises the FPE) is compared with $\mathrm{FPE}_{\mathrm{m}}{ }^{*}$. If $\mathrm{FPE}_{\mathrm{m}, \mathrm{n}}{ }^{*} \leq \mathrm{FPE}_{\mathrm{m}}{ }^{*}$ it can be concluded that $\mathrm{x} \Rightarrow \mathrm{y}$ ( $\Rightarrow$ indicates the direction of causality).

Following Islam (1998) we employed multivariate rather than the bivariate model in this study, in order to attenuate the specification bias. But the problem is that in the multivariate frame work the Hsiao method does not ensure that the result of the autoregressive (AR) equation will remain the same when the order in which regressors are introduced is changed. This problem is overcome by Caines, Keng and Sethi (1981). They proposed the "Specific Gravity" criteria (SGC) to determine the sequence in which the regressors are added to each stage $^{2}$. Thus in order to assess the importance of the nonstationarity characteristic of the data, we begin by specifying the models of the form:

$$
\begin{aligned}
& (1-L) y_{t}=\alpha_{0}+\sum_{i=1}^{l} \alpha_{i}(1-L) y_{t-i}+v_{1 t} \\
& (1-L) y_{t}=\alpha_{0}+\sum_{i=1}^{l} \alpha_{i}(1-L) y_{t-i}+\sum_{j=1}^{m} \beta_{j}(1-L) x_{t-j}+v_{2 t} \\
& (1-L) y_{t}=\alpha_{0}+\sum_{i=1}^{l} \alpha_{i}(1-L) y_{t-i}+\sum_{j=1}^{m} \beta_{j}(1-L) x_{t-j}+\sum_{k=1}^{n} \gamma_{k}(1-L) i_{t-k}+v_{3 t} \\
& (1-L) y_{t}=\alpha_{0}+\sum_{i=1}^{l} \alpha_{i}(1-L) y_{t-i}+\sum_{j=1}^{m} \beta_{j}(1-L) x_{t-j}+\sum_{k=1}^{n} \gamma_{k}(1-L) i_{t-k}+\sum_{p=1}^{q} \delta_{p}(1-L) m_{t-p}+v_{4 t}
\end{aligned}
$$

2 The "Specific Gravity Criteria" proposed by Caines, Keng and Sethi (1981) can be explained as follows. For example, in three-variable model $y=f(x, z)$ to determine the appropriate lag length of $\mathrm{y}, \mathrm{x}$ and $\mathrm{z}$ Caines et al. suggest that the first step is to determine appropriate own lag of $y$ by using FPE criteria. Using $y_{t-m}$ as a controlled variable (where $\mathrm{m}$ is the optimum lag length for $y$ ) bivariate regression are tested in which y is regressed on its own lagged value(m) and on the lagged value of one of two other variables: $y=f\left(y_{t-m}, x\right)$ and $y=$ $\mathrm{f}\left(\mathrm{y}_{\mathrm{t}-\mathrm{m}}, \mathrm{z}\right)$, considered one at a time. The two bivariate FPEs are calculated separately with the lag order $\mathrm{j}$ varying from 1 to 10 . We then compare the two bivariate FPEs with the lag length that minimises the FPE, $\mathrm{x}_{\mathrm{t}-\mathrm{p}}$ and $\mathrm{z}_{\mathrm{t}-\mathrm{q}}$ and select that which has the smaller FPE as an appropriate lag length for the trivariate equations. Next is the estimation of the trivariate regressions that add the appropriate own lags, lagged value of one of the two other variables and thus the equation, $y=f\left(y_{t-m}, x_{t-p}, z\right)$ or $y=f\left(y_{t-m}, z_{t-q}, x\right)$. The rank by which these variables are included in the equation is called the "specific gravity" criteria by Caines, Keng and Sethi (1981). 
The order of lags is chosen by using FPE criterion. In all the cases the number of lags for each endogenous variable in the system is the same. Where;

$$
\begin{aligned}
& \mathrm{y}_{\mathrm{t}}=\text { Log of real GDP } \\
& \mathrm{x}_{\mathrm{t}}=\text { Log of real exports } \\
& \mathrm{m}_{\mathrm{t}}=\log \text { of real imports } \\
& \mathrm{i}_{\mathrm{t}}=\text { Log of real investment }
\end{aligned}
$$

$\mathrm{L}=$ the lag operator $1-\mathrm{L}=\mathrm{d}$ is the difference operator such that (1-L)

$=\mathrm{y}_{\mathrm{t}}-\mathrm{y}_{\mathrm{t}-1}$ represents the first difference

$v_{t}=$ the disturbance or random error term

To test the co-integration between output exports, imports and investment, a multivariate co-integration methodology as proposed by Johansen (1988) and Johansen and Juselius (1990) is used. The advantage of this technique is that it allows one to draw a conclusion about the number of cointegrating relationships between the variables. However, in the standard bivariate cointegration technique, the parameter estimates may vary with arbitrary normalisation implicit in the selection of the left hand side variables of the regression equation, whereas the Johansen method does not rely on arbitrary normalisation. The test is based on the maximum-likelihood analysis of the VAR error-correction representation. The procedures include among others (i) data based selection of the co-integration rank (r), and (ii) testing restrictions on the co-integration space with a given rank. Limiting distributions used for the selection of the rank are completely free from all the nuisance parameters. Moreover, the test statistics on the co-integration space are asymptotically distributed as $\chi^{2}$ distribution. The two test statistics are calculated to determine the number of cointegrating vectors $(r)$ : the trace test and the maximum eigen value test.

\section{Empirical Results}

We begin our investigation by examining the basic time series properties of the data. The reason for this is that the causality analysis requires that the individual series are stationary and their co-integration properties are also examined. Because if co-integration is not accounted for, our regression models are misspecified and standard causality tests become invalid in principle. 
So before any causality analysis the integration order of the time series should be tested. The Augmented Dickey-Fuller (ADF) and Phillips-Parren (PP) tests are used for this purpose. The ADF test is based on the following equation;

$$
\Delta \mathrm{S}_{\mathrm{t}}=\alpha+\beta \mathrm{t}+\delta \mathrm{S}_{\mathrm{t}-1}+\sum_{\mathrm{j}=1}^{\mathrm{p}} \gamma_{\mathrm{j}} \Delta \mathrm{S}_{\mathrm{t}-\mathrm{j}}+\mathrm{e}_{\mathrm{t}}
$$

The lag $p$ is chosen to render the residuals free of serial correlation. We then test the composite null hypothesis $\mathrm{H}_{0}: \beta=0, \rho=1$ using the Dickey-Fuller (1981) statistic $\phi_{3}$. If $\mathrm{H}_{0}$ is rejected, there is no unit root and the presence of drift and trend can be ascertained by conventional $t$-test on $\alpha$ and $\beta$ respectively. If $\mathrm{H}_{0}$ is not rejected we re-estimate Equation (2) setting $\beta=0$ and then use the Dickey-Fuller statistic $\tau_{\mu}$, to test the hypothesis $\mathrm{H}_{0}^{\prime}: \rho=1$. If $\mathrm{H}_{0}^{\prime}$ is favoured, we get additional confirmation about the presence of a unit root. We may then resort to the statistic $\phi_{2}$ to test the null hypothesis $H_{0}^{\prime \prime}: \alpha=0, \rho=1$ Rejection of $\mathrm{H}_{0}^{\prime \prime}$ argues for the presence of a unit root with drift, and its non-rejection is defined as having a unit root without drift. The same procedure is repeated for the first differenced (growth) series, and if necessary for higher-order differenced series until a stationary series is obtained. But the Dickey-Fuller test methodology suffers from a restrictive assumption that the error term is i.i.d. When economic time series exhibit hetroscedesticity and non-normality in raw data, then PhillipsPerron (PP) test is preferable to the $\mathrm{DF}$ and $\mathrm{ADF}$ tests.

Table 1: Tests for Unit-Roots

\begin{tabular}{llllc}
\hline & \multicolumn{2}{c}{ Level } & \multicolumn{2}{c}{ First difference } \\
\hline Variables & ADF & PP & ADF & PP \\
\hline Without Time Trend & & & & \\
$\mathbf{y}_{\mathbf{t}}$ & -1.552 & -1.460 & $-3.507^{* *}$ & $-5.021^{*}$ \\
$\mathbf{x}_{\mathbf{t}}$ & -0.369 & -0.182 & $-3.596^{* *}$ & $-4.952^{*}$ \\
$\mathbf{m}_{\mathbf{t}}$ & -1.966 & -2.504 & $-4.971^{*}$ & $-4.602^{*}$ \\
$\mathbf{i}_{\mathbf{t}}$ & -2.379 & $-3.044^{* *}$ & $-2.795^{* * *}$ & $-3.206^{* *}$ \\
$\mathbf{W i t h}_{\text {Time Trend }}$ & & & & \\
$\mathbf{y}_{\mathbf{t}}$ & -1.390 & -1.412 & $-3.729^{* *}$ & $-5.150^{*}$ \\
$\mathbf{x}_{\mathbf{t}}$ & -2.281 & -2.690 & $-3.520^{* * *}$ & $-4.859^{*}$ \\
$\mathbf{m}_{\mathbf{t}}$ & -1.962 & -1.520 & $-6.031^{*}$ & $-5.090^{*}$ \\
$\mathbf{i}_{\mathbf{t}}$ & -1.457 & -1.162 & $-3.423^{* * *}$ & $-3.970^{* *}$ \\
\hline
\end{tabular}

Note: $*(* *)\{* *\}$ significant at $1 \%, 5 \%$ and $10 \%$ level. 
Phillips and Parren (1988) developed a generalisation of the DickeyFuller procedure that allows for the distribution of the errors. The procedure considers the following regression equation.

$S_{t}=\tilde{a}_{0}+\tilde{a}_{1} S_{t-1}+\tilde{a}_{2}(t-T / 2)+u_{t}$

Where $T$ is the number of observations and disturbance term $u_{t}$ is such that $\mathrm{E}\left(\mathrm{u}_{\mathrm{t}}\right)=0$, but there is no requirement that the disturbance term is serially un-correlated or homogenous. ADF test is very sensitive to the assumption of independence and homogeneity, and because of this reason the PP test is preferred over the $\mathrm{ADF}$ test.

Table 2: Johansen Cointegration Test Results

\begin{tabular}{cccccccc}
\hline \multicolumn{3}{c}{ Maximal Eigenvalue Test } & \multicolumn{4}{c}{ Trace Test } \\
\hline $\begin{array}{c}\text { Null } \\
\mathbf{H}_{\mathbf{0}}\end{array}$ & $\begin{array}{c}\text { Alternative } \\
\mathbf{H}_{\mathbf{1}}\end{array}$ & $\begin{array}{c}\text { Eigen- } \\
\text { value }\end{array}$ & $\begin{array}{c}\text { Critical } \\
\text { Value } \\
\mathbf{( 9 5 \% )}\end{array}$ & $\begin{array}{c}\text { Null } \\
\mathbf{H}_{\mathbf{0}}\end{array}$ & $\begin{array}{c}\text { Alternative } \\
\mathbf{H}_{\mathbf{1}}\end{array}$ & $\begin{array}{c}\text { LR- } \\
\text { ratios }\end{array}$ & $\begin{array}{c}\text { Critical } \\
\text { Value } \\
\mathbf{( 9 5 \% )}\end{array}$ \\
\hline $\mathrm{r}=0$ & $\mathrm{r}=1$ & 28.409 & 31.94 & $\mathrm{r}=0$ & $\mathrm{r}>1$ & 47.157 & 54.46 \\
$\mathrm{r}=1$ & $\mathrm{r}=2$ & 11.103 & 17.94 & $\mathrm{r} \leq 1$ & $\mathrm{r}>2$ & 18.748 & 35.65 \\
$\mathrm{r}=2$ & $\mathrm{r}=3$ & 6.423 & 25.52 & $\mathrm{r} \leq 2$ & $\mathrm{r}>3$ & 7.645 & 20.04 \\
$\mathrm{r}=3$ & $\mathrm{r}=4$ & 1.222 & 6.65 & $\mathrm{r} \leq 3$ & $\mathrm{r}>4$ & 1.222 & 6.65 \\
\hline
\end{tabular}

Tables 1 and 2 summarise our findings regarding integration and cointegration properties of the series. Table 1 implies that all the series are stationary at the 5\% significance level. Therefore, our causality tests are based on the growth rates of all the variables (GDP, exports, imports and investment). The results obtained from the Johansen method are reported in Table 2. Starting with the null hypothesis of no co-integration $(r=0)$ among the four non-stationary series (output, exports, imports and investment), the trace and maximal eigen value statistic are reported, both failed to reject the null hypothesis at the $5 \%$ significance level. This indicates that there is no long-run relationship existing among all these four variables.

Table 3 summarises the Hsiao test results of temporal causality between exports and growth in a multivariate frame work. The variables listed in the first column are the targeted or controlled variables. First, we consider the GDP growth as a controlled variable and found that causality runs from all three variables $\left(x_{t}, m_{t}, i_{t}\right)$ to growth. At this stage, however 
we discussed prediction (or causal) association from $\Delta \mathrm{x}_{\mathrm{t}}, \Delta \mathrm{i}_{\mathrm{t}}$ and $\Delta \mathrm{m}_{\mathrm{t}}$ to $\Delta \mathrm{y}_{\mathrm{t}}$.

In order to take the issue of bi-directional causality we must consider the reverse causation as well. We found that a bi-directional causality exists between export growth and GDP growth, investment growth and GDP growth. We also found a unidirectional causality from $\Delta \mathrm{i}_{\mathrm{t}}$ to $\Delta \mathrm{x}_{\mathrm{t}}$, $\Delta \mathrm{i}_{\mathrm{t}}$ to $\Delta \mathrm{m}_{\mathrm{t}}$ and $\Delta \mathrm{x}_{\mathrm{t}}$ to $\Delta \mathrm{m}_{\mathrm{t}}$. In addition to the direction of causality, the signs of the causal relation between $\mathrm{x}_{\mathrm{t}}$ and $\mathrm{y}_{\mathrm{t}}, \mathrm{m}_{\mathrm{t}}$ and $\mathrm{y}_{\mathrm{t}}$ and $\mathrm{i}_{\mathrm{t}}$ and $\mathrm{y}_{\mathrm{t}}$ are also of great importance. To determine the direction of causality between the dependent and the independent variables (+ or - relationship), the sign of the sum of coefficients of lagged values of the causal factor is reported. For this purpose the $t$ and $F$ - tests have been performed and the corresponding statistics are reported in Table 4 . Theses indicate that there exists a positive relationship between export and growth in both directions. Also there is a positive bi-directional relationship between growth and investment, where as imports and growth has a uni-directional positive relationship. Also, exports and imports have uni-directional positive causality. We found a positive relationship between investment and exports, because a higher demand for investment causes a rise in exports. So this result confirms our investment led growth hypothesis as well. Hence, on the basis of our findings we can say that both exports and investment are the major factors that affect the economic growth of Pakistan. 
Table 3: Hsiao's Version of the Granger Causality Tests

\begin{tabular}{|c|c|c|c|c|c|}
\hline \multicolumn{6}{|c|}{ Order of Regresssors } \\
\hline $\begin{array}{l}\text { Controlled } \\
\text { Variable }\end{array}$ & $\begin{array}{l}\text { First } \\
\text { Manipulated } \\
\text { Variable }\end{array}$ & $\begin{array}{l}\text { Second } \\
\text { Manipulated } \\
\text { Variable }\end{array}$ & $\begin{array}{l}\text { Third } \\
\text { Manipulated } \\
\text { Variable }\end{array}$ & FPE & $\begin{array}{l}\text { Causality } \\
\text { Inference }\end{array}$ \\
\hline$\Delta y_{t}(i=1)$ & - & - & - & 0.0913 & - \\
\hline$\Delta y_{t}(i=1)$ & $\Delta \mathrm{i}_{\mathrm{t}}(\mathrm{j}=5)$ & - & - & 0.0888 & $I N V E S T \Rightarrow G D F$ \\
\hline$\Delta y_{t}(\mathrm{i}=1)$ & $\Delta \mathrm{i}_{\mathrm{t}}(\mathrm{j}=5)$ & $\Delta \mathrm{m}_{\mathrm{t}}(\mathrm{k}=2)$ & $\Delta \mathrm{x}_{\mathrm{t}}(\mathrm{m}=1)$ & 0.0776 & $\mathrm{IMP} \Rightarrow \mathrm{GDP}$ \\
\hline$\Delta y_{t}(\mathrm{i}=1)$ & $\Delta \mathrm{i}_{\mathrm{t}}(\mathrm{j}=5)$ & $\Delta \mathrm{m}_{\mathrm{t}}(\mathrm{k}=2)$ & $\Delta \mathrm{x}_{\mathrm{t}}(\mathrm{m}=1)$ & 0.0772 & $E X P \Rightarrow G D P$ \\
\hline$\Delta \mathrm{i}_{\mathrm{t}}(\mathrm{i}=3)$ & - & - & - & $0.207 \mathrm{E}^{-02}$ & - \\
\hline$\Delta \mathrm{i}_{\mathrm{t}}(\mathrm{i}=3)$ & $\Delta y_{t}(j=2)$ & - & - & $0.192 \mathrm{E}^{-02}$ & $G D P \Rightarrow I N V E S T$ \\
\hline$\Delta \mathrm{i}_{\mathrm{t}}(\mathrm{i}=3)$ & $\Delta y_{t}(j=2)$ & $\Delta \mathrm{m}_{\mathrm{t}}(\mathrm{k}=1)$ & $\Delta \mathrm{x}_{\mathrm{t}}(\mathrm{m}=1)$ & $0.201 \mathrm{E}^{-02}$ & $I M P \neq>I N V E S T$ \\
\hline$\Delta \mathrm{i}_{\mathrm{t}}(\mathrm{i}=3)$ & $\Delta y_{t}(j=2)$ & $\Delta \mathrm{m}_{\mathrm{t}}(\mathrm{k}=1)$ & $\Delta \mathrm{x}_{\mathrm{t}}(\mathrm{m}=1)$ & $0.214 \mathrm{E}^{-02}$ & $E X P \neq>I N V E S T$ \\
\hline$\Delta \mathrm{x}_{\mathrm{t}}(\mathrm{i}=2)$ & - & - & - & 0.0148 & - \\
\hline$\Delta \mathrm{x}_{\mathrm{t}}(\mathrm{i}=2)$ & $\Delta y_{t}(j=5)$ & - & - & 0.0142 & $G D P \Rightarrow E X P$ \\
\hline$\Delta \mathrm{x}_{\mathrm{t}}(\mathrm{i}=2)$ & $\Delta y_{t}(j=5)$ & $\Delta \mathrm{i}_{\mathrm{t}}(\mathrm{k}=4)$ & $\Delta \mathrm{m}_{\mathrm{t}}(\mathrm{m}=1)$ & 0.0115 & $I N V E S T \Rightarrow E X P$ \\
\hline$\Delta \mathrm{x}_{\mathrm{t}}(\mathrm{i}=2)$ & $\Delta y_{t}(j=5)$ & $\Delta \mathrm{i}_{\mathrm{t}}(\mathrm{k}=4)$ & $\Delta \mathrm{m}_{\mathrm{t}}(\mathrm{m}=1)$ & 0.0121 & $I M P \neq>E X P$ \\
\hline$\Delta \mathrm{m}_{\mathrm{t}}(\mathrm{i}=2)$ & - & - & - & $0.807 \mathrm{E}^{-02}$ & - \\
\hline$\Delta \mathrm{m}_{\mathrm{t}}(\mathrm{i}=2)$ & $\Delta \mathrm{i}_{\mathrm{t}}(\mathrm{j}=3)$ & - & - & $0.626 \mathrm{E}^{-02}$ & $I N V E S T \Rightarrow I M P$ \\
\hline$\Delta \mathrm{m}_{\mathrm{t}}(\mathrm{i}=2)$ & $\Delta \mathrm{i}_{\mathrm{t}}(\mathrm{j}=3)$ & $\Delta \mathrm{x}_{\mathrm{t}}(\mathrm{k}=1)$ & $\Delta \mathrm{y}_{\mathrm{t}}(\mathrm{m}=2)$ & $0.572 \mathrm{E}^{-02}$ & $E X P \Rightarrow I M P$ \\
\hline$\Delta m_{t}(i=2)$ & $\Delta \mathrm{i}_{\mathrm{t}}(\mathrm{j}=3)$ & $\Delta \mathrm{x}_{\mathrm{t}}(\mathrm{k}=1)$ & $\Delta y_{t}(m=2)$ & $0.594 \mathrm{E}^{-02}$ & $G D P \neq>I M P$ \\
\hline
\end{tabular}

Note: the values in parenthesis are the number of lags included. $\Rightarrow$ shows the direction of causality.

In order to test the constancy of the causality inferences, the Cumulative Sum (CUSUM) of squares test described by Brown et al. (1975) has been applied; the test is based on the cumulative sum of the squared 
recursive residuals ${ }^{3}$. The CUSUM test gives a plot of the cumulative sum of squared residuals, together with two critical lines.

Table 4: The $t$ and F-Statistic

\section{Growth Equation:}

$$
\begin{gathered}
\Delta \mathrm{y}_{\mathrm{t}}=-\alpha_{0}-\sum_{\mathrm{i}=1}^{1} \alpha_{1 \mathrm{i}} \Delta \mathrm{y}_{\mathrm{t}-\mathrm{i}}+\sum_{\mathrm{j}=1}^{5} \alpha_{2 \mathrm{j}} \Delta \mathrm{i}_{\mathrm{t}-\mathrm{j}}+\sum_{\mathrm{k}=1}^{2} \alpha_{3 \mathrm{k}} \Delta \mathrm{m}_{\mathrm{t}-\mathrm{k}}+\sum_{\mathrm{m}=1}^{1} \alpha_{4 \mathrm{~m}} \Delta \mathrm{x}_{\mathrm{t}-\mathrm{m}}+\mathrm{v}_{1 \mathrm{t}} \\
(-0.27)
\end{gathered}
$$

Export Equation:

$$
\begin{gathered}
\Delta \mathrm{x}_{\mathrm{t}}=\alpha_{0}+\sum_{\mathrm{i}=1}^{2} \alpha_{1 \mathrm{i}} \Delta \mathrm{x}_{\mathrm{t}-\mathrm{i}}+\sum_{\mathrm{j}=1}^{5} \alpha_{2 \mathrm{j}} \Delta \mathrm{y}_{\mathrm{t}-\mathrm{j}}+\sum_{\mathrm{k}=1}^{4} \alpha_{3 \mathrm{k}} \Delta \mathrm{i}_{\mathrm{t}-\mathrm{k}}-\sum_{\mathrm{m}=1}^{1} \alpha_{4 \mathrm{~m}} \Delta \mathrm{m}_{\mathrm{t}-\mathrm{m}}+\mathrm{v}_{2 \mathrm{t}} \\
\quad \text { (0.34) }
\end{gathered}
$$

Investment Equation:

$$
\begin{aligned}
\Delta \mathrm{i}_{\mathrm{t}}= & \alpha_{0}+\sum_{\mathrm{i}=1}^{3} \alpha_{1 \mathrm{i}} \Delta \mathrm{i}_{\mathrm{t}-\mathrm{i}}+\sum_{\mathrm{j}=1}^{2} \alpha_{2 \mathrm{j}} \Delta \mathrm{y}_{\mathrm{t}-\mathrm{j}}-\sum_{\mathrm{k}=1}^{1} \alpha_{3 \mathrm{k}} \Delta \mathrm{m}_{\mathrm{t}-\mathrm{k}}+\sum_{\mathrm{m}=1}^{1} \alpha_{4 \mathrm{~m}} \Delta \mathrm{x}_{\mathrm{t}-\mathrm{m}}+\mathrm{v}_{3 \mathrm{t}} \\
& (0.63)
\end{aligned}
$$

Import Equation:

$$
\begin{gathered}
\Delta \mathrm{m}_{\mathrm{t}}=-\alpha_{0}-\sum_{\mathrm{i}=1}^{2} \alpha_{1 \mathrm{i}} \Delta \mathrm{m}_{\mathrm{t}-\mathrm{i}}+\sum_{\mathrm{j}=1}^{3} \alpha_{2 \mathrm{j}} \Delta \mathrm{i}_{\mathrm{t}-\mathrm{j}}+\sum_{\mathrm{k}=1}^{1} \alpha_{3 \mathrm{k}} \Delta \mathrm{x}_{\mathrm{t}-\mathrm{k}}+\sum_{\mathrm{m}=1}^{2} \alpha_{4 \mathrm{~m}} \Delta \mathrm{y}_{\mathrm{t}-\mathrm{m}}+\mathrm{v}_{4 \mathrm{t}} \\
(-0.69)
\end{gathered}
$$

Note: The values in ( ) are the t-statistics. The values in [ ] are the Fstatistics.

${ }^{3}$ The CUSUM squares test is based on the test statistic:

$$
\mathrm{S}_{\mathrm{t}}=\frac{\sum_{\mathrm{i}=\mathrm{k}+1}^{\mathrm{t}} \mathrm{w}_{\mathrm{i}}^{2}}{\sum_{\mathrm{i}=\mathrm{k}+1}^{\mathrm{n}} \mathrm{w}_{\mathrm{i}}^{2}}, \quad \mathrm{t}=\mathrm{k}+1, \mathrm{k}+2, \ldots \ldots \ldots \ldots . ., \mathrm{n} .
$$

where $s$ is the standard error of the regression fitted to all i sample points, and $\mathrm{w}_{\mathrm{i}}{ }^{2}$ is the squared recursive residuals. The mean value line which provides the expected value of this test statistic under the hypothesis

$$
\mathrm{E}\left(\mathrm{S}_{\mathrm{t}}\right)=\frac{\mathrm{t}-\mathrm{k}}{\mathrm{n}-\mathrm{k}}
$$




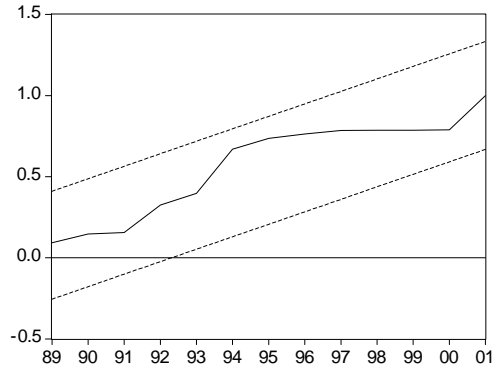

(a)

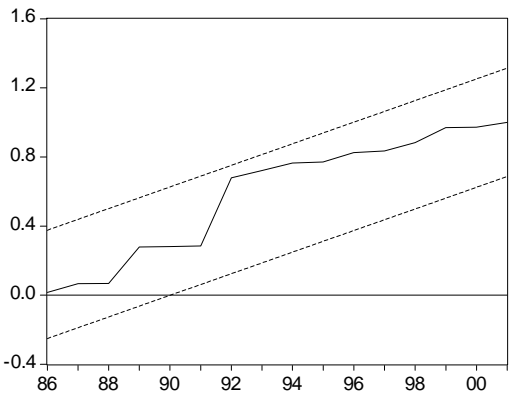

(c)

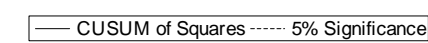

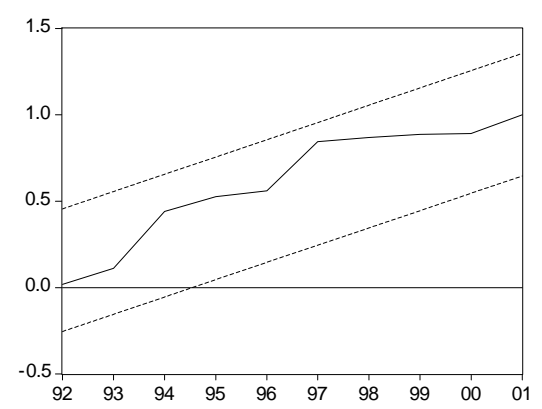

(b)

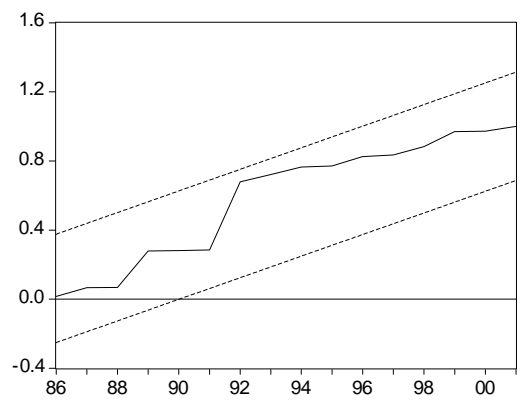

d)

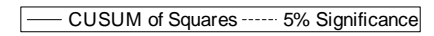

Fig.1. The CUSUM of squares test: (a) Growth equation (b) Export equation (c) Investment equation (d) Import equation. ( ) CUSUM of squares (----) $5 \%$ significance.

If the cumulative sum moves outside the region between the two critical lines, parameter instability is suggested. In panels (a),(b),(c),(d) of Fig.1, the computed CUSUM of Squares test has been utilised to examine the parameter estimates during the entire time period (1973-2001). In all cases the null hypothesis of parameter stability cannot be rejected at the $5 \%$ significance leve1. Hence our causality results are consistent over the entire sample period.

\section{Concluding Remarks:}

In contrast to the existing studies in export-growth analysis in which the bivariate causality test has been performed, in most of the cases it is found to be inconclusive. The major shortcoming with the bivariate causality analysis is the omission of the other relevant variables, such 
omission can create bias in the results or the inferences drawn on the basis of these results are biased.

We used multivariate causality analysis by introducing imports and investment in our model in order to overcome the problem of specification biasedness which leads to spurious causality findings (because of the omission of particular variables from the regression). An analysis solely being based on exports leads to model misspecification if imports and investment are relevant variables. The evidence indicates that the export driven GDP growth hypothesis is supported in the presence of imports and investment as additional factors. Also we found a positive association between investment and economic growth in both directions. 
Aurangzeb 133

\section{References}

Abhayaratne, A.S.P. 1996 Foreign trade and economic growth evidence from Sri Lanka, 19960-1992, Applied Economics Letters 3, 567-70

Afexntiou, P.C. and Serletis, A. 1992 Openness in the Canadian Economy: 18701988, Applied Economics, 24, 1191-8

Akaike, H. 1969 Statistical predictor identification, Annals of the Institute of Statistical Mathematics, 21, 207-17.

Amoateng, K. and Amoako-Adu, B. 1996 Economic growth, export and external debt causality: the case of African countries, Applied Economics, 28, 21-27.

Arnade, C. and Vasavada, U. 1995 Causality between productivity and exports in agriculture: evidence from Asia and Latin America, Journal of Agricultural Economics 46 (2), 174-86

Bahmani-Oskooee, Mohsen and Alse, J. 1985 Export growth and economic growth: an application of co-integration and error-correction modeling, Journal of Developing Areas 27.

Bahmani-Oskooee, Mohsen, Mohtadi, H. and Shabsigh, G. 1991 Export, growth and causality in LDCs: a re-examination, Journal of Development Economics, $36,405-15$

Balassa, B. 1985 Exports, policy choices and economic growth in developing countries after the 1973 oil shock, Journal of Development Economics 26, $55-63$

Ben-David, Dani and Michael Loewy, 1997 Free trade, growth and convergence, Economic Research Network Working Paper A1.83 WP 6095.

Brown, R. L. Durbin, J. and Evans, J. M. 1975 Techniques for testing the constancy of regression relationship over time, Journal of the Royal Statistical Society, 2, 149-92.

Caines, P.E.C., Keng, W. and Sethi, S.P. 1981 Causality analysis and multivariate autoregressive modeling with an application to supermarket sales analysis, Journal of Economic Dynamics and control, 3, 697-708.

Chow, P.C. Y. 1987 Causality between export growth and industrial development, Journal Of Development Economics 26, 55-63. 
134 The Lahore Journal of Economics, Vol.8, No.1

Dodaro, S. 1993 Export and growth: a reconsideration of causality, Journal of Developing Areas, 27, 227-44.

Doraisami, A. 1996 Export growth and economic growth a re-examination of some time-series evidence of the Malaysian experience, The Journal of Development Areas, 30, 223-30.

Esfahani, H.S. 1991 Exports, imports, and economic growth in semi-industrialized countries, Journal of Development Economics, 35, 93-116.

Feder, G. 1982 On exports and economic growth, Journal of Development Economics, 12, 59-75.

Fuller, W.A. 1976 Introduction to Statistical Time-Series, New York, N.Y. John Wiley, 371-73.

Ghartey, E. 1993 Causal relationship between exports and economic growth: some empirical evidence in Taiwan, Japan and the US, Applied Economics, 25, 553-63

Gordon, D.V and Sakyi-Bekoe, K. 1993 testing the export growth hypothesis: some parametric and non-parametric results for Ghana, Applied Economics, 25 555-63

Granger C.W. 1969 investigating causal relations by econometric models and gross spectral methods, Econometrica, 37, 424-38.

Granger C.W. 1988 some recent developments in concept of causality, Journal of Econometrics, 39, 199-211

Helpman, E. and Krugman, P. 1985 Market Structure and Foreign Trade, MIT Press, Cambridge, MA.

Hsiao, C. 1979 Autoregressive modeling and money-income causality detection, Journal of American Statistical Association, 74, 553-60.

Hsiao, C. 1981 Autoregressive modeling and money-income causality detection, Journal of money economics, 7, 321-46.

Hsiao, C. 1987 Tests of causality and exogeneity between exports and economic growth: the case of Asian NICs, Journal of Economic Development, 12, 143-59.

Islam, M.N. 1998 Export expansion and economic growth: testing for cointegration and causality, Applied Economics, 30, 415-25. 
Jacobs, R.L., E.E. Leamer and M.P. Ward 1979 Difficulties with testing for causality, Economic Inquiry, 17, 401-13.

Johansen, S. 1988 Statistical analysis of cointegration vectors, Journal of Economic Dynamic and Control, 12, 231-54.

Johansen, S. and Juselius, K. 1990 Maximum likelihood estimation and inference on cointegration with applications for the demand for money, Oxford Bulletin of Economics and Statistics, 52, 169-210

Jung, W.S. and Marshall, P.J. 1985 Exports growth and causality in developing countries. Journal of Development Economics, 18, 1-12

Kaldor, N. 1967 Strategic Factors in Economic Development, Cornell University, NY.

Kavoussi, R.M. 1984 Export expansion and economic growth: further empirical evidence, Journal of Development Economics, 14, 241-50.

Khan, A.H. Malik, A. and Hasan, L. 1995 Exports, Growth and Causality: An Application of co-integration and error-correction modeling, The Pakistan Development Review, 34(4), 1001-12.

Krihna, K. 1992 Openness: a conceptual approach, Working Paper, Pennsylvania State University.

Krueger, A. O. 1978 Foreign trade regimes and economic development: Liberalization attempts and consequences, Ballinger, Cambridge.

Krueger, A. O. 1985 The experience and lessons of Asia's super exporters, in V. Corbo, A.Krueger, and F. Ossa (eds) Export-oriented Development Strategies: the success of five newly industrializing countries, West View Press, Boulder, Co.

Kugler, P. and Lenz, C. 1993 Multivariate cointegration analysis and the long-run validity of PPP, Review of Economics and Statistics, 75, 180-84

Kunst, R.M. and Marin, D. 1989 On exports and productivity: a causal analysis, Review of Economics and Statistics, 71, 695-703.

Liu, X., Song, H. and Romilly, P. 1997 An empirical investigation of the causal relationship between openness and economic growth in China, Applied Economics, 29, 1676-86. 
136 The Lahore Journal of Economics, Vol.8, No.1

Mabku, J. 1989 Export growth and economic performance in developing countries: further evidence from Africa, Journal of Economic Development, 14(2), 4953.

Michealy, M. 1977 Exports and growth: an empirical investigation, Journal of Development Economics 4, 49-53

Moschos, D. 1989 Exports expansion, growth and the level of economic development, Journal of Development Economics, 30, 93-102.

Pack, H. 1988 Industrialization and Trade, in H. Chenery and T.N. Srinivasan (eds) Handbook of Development Economics, Elsevier, Amsterdam.

Pack, H. 1992 Learning and productivity changes in developing countries in G.K. Helleiner (ed.) Trade policy, Industrialization, and Development, Clarendon Press, Oxford.

Phillips, P.C.B and Perron, P. 1988 Testing for a unit root in time series regression, Biometrika, 75, 335-46.

Pritchett, L. 1996 Measuring outward orientation in developing countries: can it be done? Journal of Development Economics, 49, 307-335.

Rodrik, D. 1988 Closing the technology gap: does trade liberalization really help? Cambridge NBER working paper no. 2654

Rodrik, D. 1995 Comments in trade policies and developing nations by Anne O. Kruege, Washington D.C.: The Brookings Institutions.

Salvatore, D. and Hatch, T. 1991 Inward oriented and outward oriented trade strategies. The Journal of Development Studies 27(3), 7-25.

Serletis, A. 1992 Export growth and Canadian economic development, Journal of Development Economics, 38, 133-45.

Sharma, S.C. and Dhaka1, D. 1994 Causal analysis between exports and economic growth in developing countries, Applied Economics, 38, 133-45.

Sheehey, E. 1990 Exports and growth a flawed framework, The Journal of Development Studies, 27, 111-16.

Syrquin, M. 1988 Patterns of structural change, in H. Chenrey and T.N. Srivassan (eds) Handbook of Development Economics, Elsevier, Amsterdam. 
Thornton, D.L. and Batten, D.S. 1985 Lag-length selection and tests of Granger causality between money and income, Money, Credit and Banking, 17, 164-78.

Timmer, P. 1988 the agricultural transformation, in H. Chenery and T.N. Srivassan (eds) Handbook of Development Economics, Elsevier, Amsterdam.

Tyler W.G. 1981 Growth and export expansion in developing countries: some empirical evidence, Journal of Development Economics, 9, 121-30

Vernon, R. 1966 International investments and international trade in the product cycle, Quarterly Journal of Economics, 80, 190-207.

Voivodas, C. 1973 Exports, foreign capital inflows and economic growth, Journal of International Economics, 3, 337-49.

Yaghmaian, B. 1994 An empirical investigation of exports, development and growth in developing countries: challenging the neo-classical theory of export-led growth, World Development, 22, 1977-95.

Wu, De-Min 1983 Tests of causality, predeterminedness and exogeneity, International Economic Review, 24(3), 547-88.

Young, Alwyn, 1994, Lessons from East Asian NICS: a Contrarian's View, European Economic Review, 38, 964-73. 